\title{
Effect of human chorionic gonadotrophin on dominant follicles in cows: formation of accessory corpora lutea, progesterone production and pregnancy rates
}

\author{
R. Rajamahendran and P. C. Sianangama \\ Department of Animal Science, University of British Columbia Vancouver, British Columbia, \\ Canada V6T $2 A 2$
}

\begin{abstract}
Summary. Thirty-four lactating Holstein cows were randomly assigned to four groups for treatment with human chorionic gonadotrophin (hCG, $1000 \mathrm{iu}$ ) at insemination day $0(n=8)$ or $7(n=9)$ or 14 days $(n=9)$ after insemination or with no hCG treatment (control, $n=8$ ). Ultrasound imaging of the ovaries and plasma progesterone measurements were carried out to determine follicular dynamics and corpus luteum growth and function. Rates of formation of accessory corpora lutea were higher among cows treated on days 0 (three cows), 7 (seven cows) or 14 (four cows) than in the controls (one cow). Total corpus luteum diameter was greater $(P<0.01)$ among hCGtreated cows than in controls 7-42 days after insemination. Concentrations of progesterone in plasma were significantly $(P<0.05)$ higher in cows treated with hCG on days 7 or 14 than in those treated on day 0 or in controls, at days 18,35 or 42 after insemination. Seven of the cows treated on day 7 became pregnant, whereas four, four and three cows treated on days 0 or 14 and control cows became pregnant, respectively. The results suggest that hCG treatment at 7 days after insemination could be used to produce accessory corpora lutea, raise plasma progesterone concentration and hence reduce the incidence of early embryonic mortality in cattle.
\end{abstract}

Key'words: follicle; corpus luteum; progesterone; pregnancy; human chorionic gonadotrophin; cow

\section{Introduction}

The necessity of the corpus luteum for the establishment and maintenance of early pregnancy in domestic animals is well documented (Henricks et al., 1970; Randel et al., 1971; Erb et al., 1976; Bulman \& Lamming, 1978). Many cows that fail to maintain pregnancies tend to have low progesterone concentrations in the early and mid-luteal phases (Bulman \& Lamming, 1978). It has been suggested that, in such animals, the corpus luteum may not be functioning optimally, suggesting inadequate function, long suspected to occur in cattle, causing substantial losses in reproduction (Henricks et al., 1970; Erb et al., 1976; Lukaszewska \& Hansel, 1980; Wilmut et al., 1985). Measures for correcting this reproductive failure have included (i) the use of exogenous progesterone (Northey et al., 1985; Robinson et al., 1989), (ii) administration of human chorionic gonadotrophin (hCG) (Veenhuizen et al., 1972; Wagner et al., 1973; Holness et al., 1982; Breuel et al., 1990) and (iii) gonadotrophin-releasing hormone (Nakao et al., 1983; Lewis et al., 1990), after insemination. Results obtained with these methods have, however, not consistently improved pregnancy rates.

The purpose of this study was to develop a treatment for reducing embryonic mortality that may be attributed to inadequate function of the corpus luteum. It was postulated that supplementing endogenous progesterone production can be achieved most efficiently by inducing the development of accessory corpora lutea. Ideally, healthy, large follicles should be present during induction 
of formation of accessory corpora lutea. Studies using ultrasound imaging in heifers and cows have shown oestrous cycles characterized by two waves of follicular growth (Pierson \& Ginther, 1987, 1988; Rajamahendran \& Taylor, 1990) and cycles with three waves (Savio et al., 1988; Sirois \& Fortune, 1988). These waves culminate in the emergence of at least one large follicle on the day of oestrus and insemination (day 0 ), at 7 and occasionally 14 days after oestrus or insemination (Taylor \& Rajamahendran, 1991a, b). Reports also indicate that these large follicles possess luteinizing hormone receptors (Ireland \& Roche, 1983; Ireland, 1987), the concentrations of which vary with the stage of the oestrous cycle (Bennet et al., 1989). This suggests that large follicles would respond to gonadotrophins.

This study evaluated the use of hCG to induce ovulation of large follicles present either at the time of insemination, or 7 or 14 days after insemination, and the effect of such treatment on progesterone concentrations and pregnancy rates. The clinical significance was the potential use of hCG to supplement endogenous progesterone to overcome early embryonic mortality.

\title{
Materials and Methods
}

\begin{abstract}
Animals
Thirty-four cyclic lactating Holstein cows, 3-6 years old and 60-90 days post partum, were selected at random between October 1989 and April 1990 from the dairy herd at the University of British Columbia. Ambient temperature during the experimental period ranged from $-2^{\circ}$ to $+15^{\circ} \mathrm{C}$. Cows received a mixed ration of lucerne cubes and barley and canola concentrate based on equal proportions, providing a diet of about $16 \%$ crude protein with total ration adjusted to the cows' milk production. Cows were milked twice a day, between 03:00 and 05:00 $\mathrm{h}$ and between $14: 30$ and 16:30 h. Cows were checked for signs of oestrus at both milkings and for about 30 min during the mid-morning. All cows were mated using artificial insemination approximately $12 \mathrm{~h}$ after the onset of standing oestrus.
\end{abstract}

\section{Treatment with hCG}

At mating, cows were randomly assigned to one of four treatment groups. A single intramuscular injection of hCG ( $1000 \mathrm{iu}$, APL $R$, Ayerst Laboratories, Montreal, Canada) was given either at the time of insemination (day $0, n=8$ ), or on day $7(n=9)$ or day $14(n=9)$ after insemination; the control group $(n=8)$ received no hCG injection.

\section{Ultrasound examination of the reproductive tracts}

A real-time ultrasound scanning device (Ultrasound scanner, model LS 300, Tokyo Keiki Company Limited, Tokyo, Japan) equipped with a $5 \mathrm{MHz}$ rectal probe was used to examine the ovaries and the uterine horns, as described by Rajamahendran \& Taylor (1990) and Taylor \& Rajamahendran (1991a). Ultrasound scanning was carried out on days $7,9,11,14,16,18,21,28,35$ and 42 after insemination or until the first observed oestrus before day 42. Ovulations resulting from treatment with hCG were verified by observing the disappearance of one or more of the large follicles present at the time of administering the treatment. The emergence of an induced corpus luteum was characterized by luteal tissue appearing on a site previously occupied by large follicle(s). The dimensions of spontaneous and induced corpora lutea (total diameter) and large follicles were obtained using a built-in system of calibrated callipers. Hard copies of the frozen images of the ovary bearing the corpora lutea and follicles were obtained using a Mitsubishi Video copy processor (Model number P60U, Mitsubishi Electric Sales America Inc., Cypress, CA, USA) connected to the ultrasound scanner.

\section{Collection of blood samples and progesterone radioimmunoassay}

At the time of ultrasound evaluation, each animal was bled via the coccygeal vein or artery and $10 \mathrm{ml}$ of blood was collected in heparinized vacutainer tubes (Becton Dickinson, Vacutainer systems, Rutherford, NJ, USA). All blood samples were centrifuged $(4000 \mathrm{~g})$ within $1 \mathrm{~h}$ of collection and plasma was separated and frozen at $-20^{\circ} \mathrm{C}$ until assayed for progesterone. Measurements of progesterone concentrations in plasma were performed with a direct, solid-phase, ${ }^{125} \mathrm{I}$-labelled steroid radioimmunoassay kit manufactured by Diagnostics Products Corporation (DPC, Los Angeles, CA, USA), which had been validated for measuring progesterone in bovine plasma (Rajamahendran \& Taylor, 1990). The intra-assay coefficient of variation (CV) was $7.9 \%$; the interassay CVs for the oestrous, early and late dioestrous samples were $10 \cdot 3,11 \cdot 0$ and $9 \cdot 7 \%$, respectively. 


\section{Pregnancy diagnosis}

Establishment of pregnancy was verified using the ultrasound scanner (Taylor \& Rajamahendran, 1991a). The uterine horns were scanned over their entire length and in several planes to identify embryonic vesicles and embryos. Detection of embryonic vesicles was possible by day 21 after insemination. The fetus could be identified on day 28 after insemination. Animals not returning to oestrus were scanned again at $35,42,60$ and 80 days after insemination to confirm pregnancy and to determine the fate of induced corpora lutea.

\section{Statistical analysis}

Data for total diameter of corpora lutea and plasma progesterone were analysed using a split-plot experimental design. The least-squares analysis of variance procedure in the General Linear Models, SAS (SAS Institute, Inc.), was used to test for differences among treatments.

\section{Results}

\section{Induction of accessory corpora lutea}

Ultrasound scanning of the ovaries of control cows at day 7 after insemination revealed that six cows had single ovulation; one had spontaneous twin ovulations (Fig. 1a); and another failed to ovulate. Among cows treated with hCG at day 0 , three cows each had two corpora lutea (Fig. 1b); one cow in this group did not ovulate and developed a cystic follicle, which appeared luteinized, as shown by a fine luteal-like grainy layer circumscribing the dark follicular structure (Fig. 1c). The remaining four cows in this group, had single ovulation.

Among cows treated with hCG on day 7 after insemination, the largest and second largest follicles present at the time of administering the treatment ranged from 13 to 22 and from 9 to $21 \mathrm{~mm}$ in diameter, respectively. The largest follicle ovulated in four cows after treatment with hCG. The induced corpus luteum was contralateral $(n=2)$ or ipsilateral $(n=2)$ to the spontaneous corpus luteum. In the fifth cow, the largest follicle on one ovary and the second largest follicle on the other ovary ovulated. This cow also had twin spontaneous ovulations (Fig. 1d). In another two cows, the second largest follicle ipsilateral to the spontaneous corpus luteum ovulated. The largest follicles in these two cows were present after the emergence of the induced corpus luteum, but subsequently regressed. In the two remaining cows, none of the large follicles ovulated. In the group treated on day 14 , large follicles $(9-27 \mathrm{~mm})$ were present in all cows when hCG was administered. Four out of nine cows formed accessory corpora lutea. In these cows, the largest follicle present at the time of treatment failed to ovulate. The ovulatory follicle was the second largest in three cows, located contralateral to the spontaneous corpus luteum. In the fourth cow, the third largest follicle $(9 \mathrm{~mm})$, ipsilateral to the spontaneous corpus luteum, ovulated (Fig. le).

\section{Growth of corpora lutea}

On day 7 after insemination, corpora lutea of cows treated on day 0 had a significantly larger $(P<0.05)$ diameter than those in any of the other groups (Fig. 2a). At day 14, cows treated on day 7 had corpora lutea with significantly larger $(P<0.001)$ diameters than those in the other groups. A slight decline in diameter was observed in corpora lutea of all treated and control cows on days $21,28,35$ and 42 , but the least-squares means were significantly higher $(P<0.01)$ for day 7 than for other groups.

\section{Persistence of corpora lutea}

After fertile inseminations, induced corpora lutea were present until the termination of the experiment (Fig. 2b). However, in one pregnant cow, treated on day 0 , one of the double corpora lutea regressed by day 21 . The induced corpora lutea were smaller throughout the experimental 


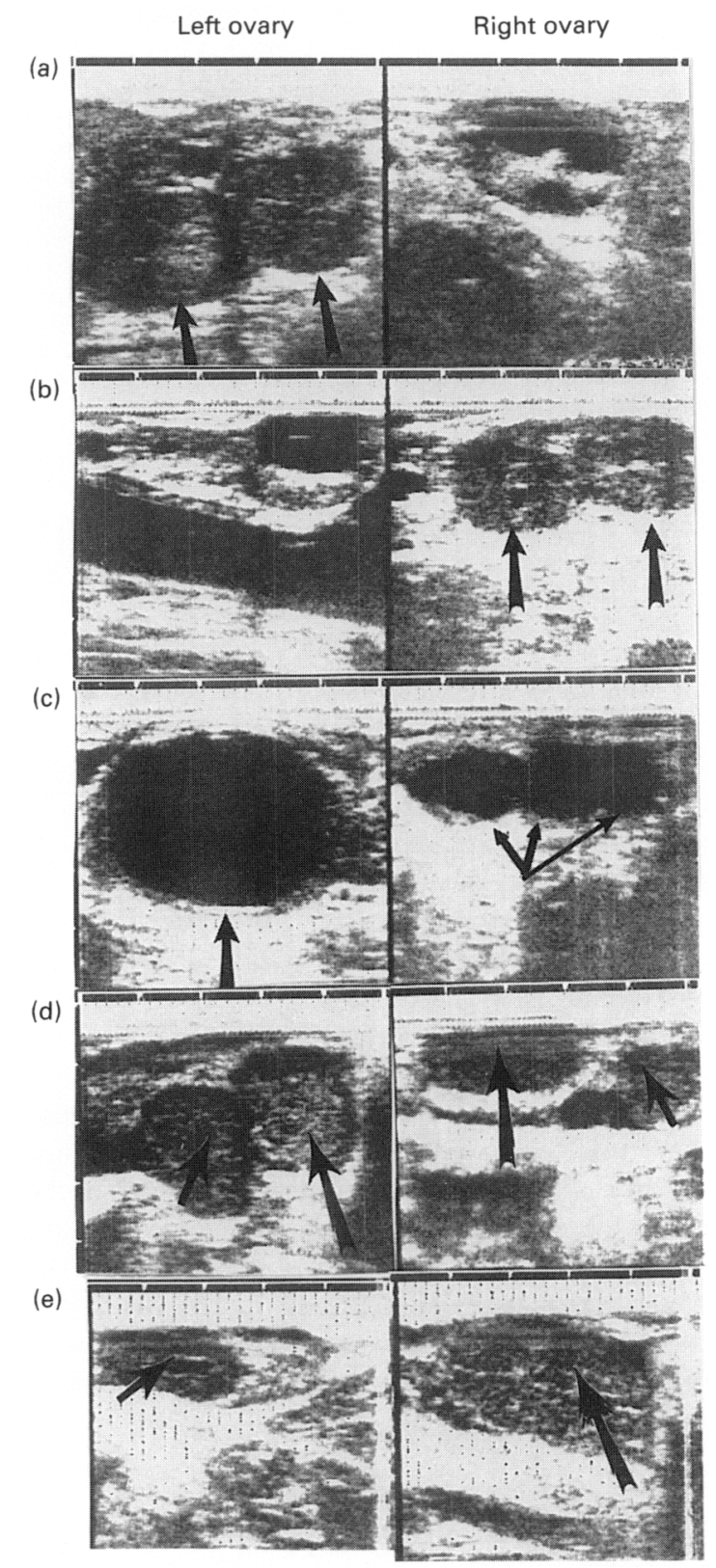

Fig. 1. Ultrasound pictures of left and right ovaries showing double corpora lutea in (a) a control cow and (b) a cow treated with human chorionic gonadotrophin (hCG) at day 0 , and (c) cystic follicle (left ovary) in a cow treated at day 0 ; induced corpora lutea were observed after hCG given either at day 7 (d, short arrow) or day 14 (e, short arrow) after insemination. Long arrows $(d, e)$ indicate spontaneous corpora lutea. Images a-c, $d$ and e were taken on 7, 14 and 21 days after insemination, respectively.

period. After nonfertile inseminations, induced and spontaneous corpora lutea regressed at the same time, which was $19.7 \pm 0.9,20.7 \pm 0.4,23.4 \pm 1.9$ and $21.4 \pm 1.9$ days for day 0 , day 7 , day 14 and control cows, respectively. 

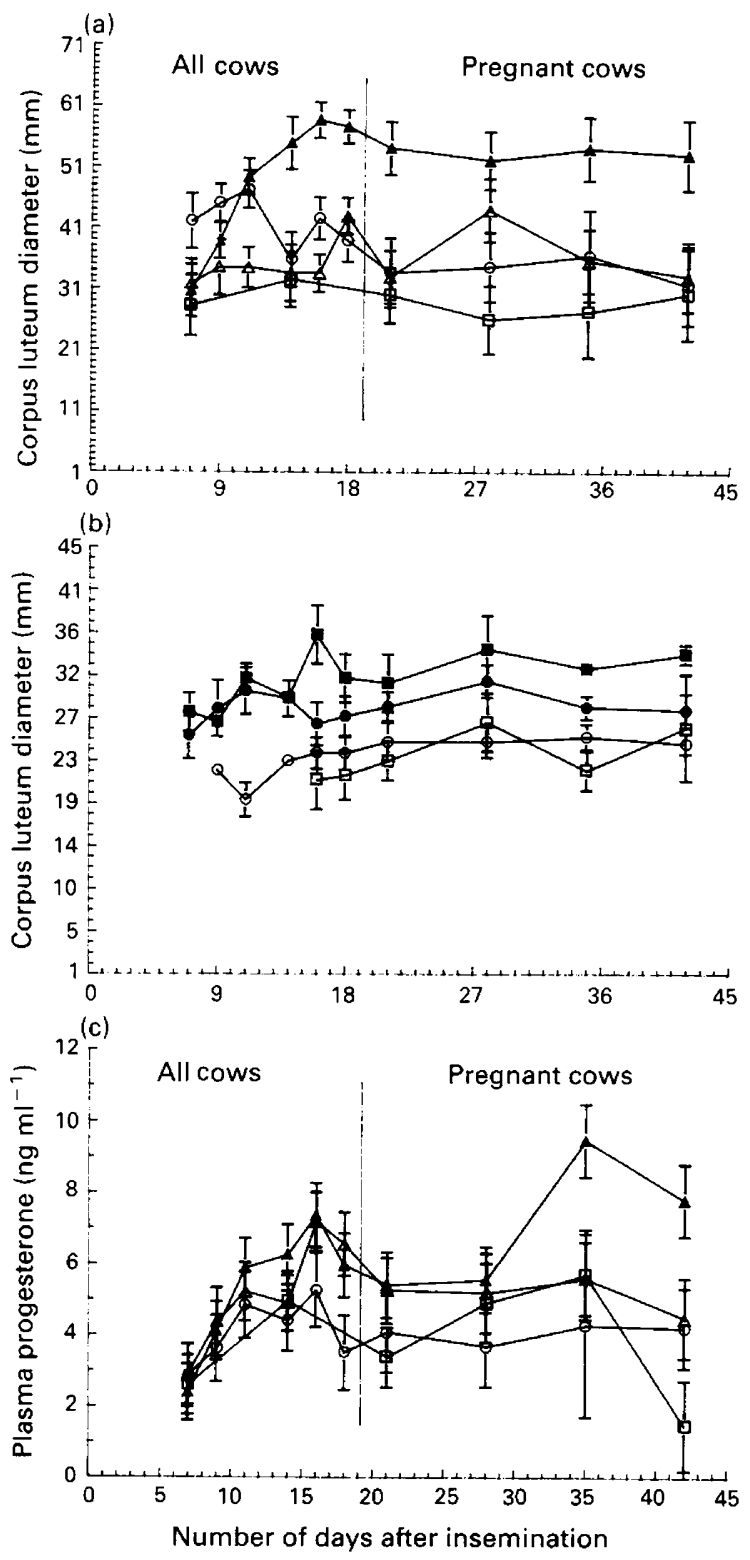

Fig. 2. Mean ( \pm SEM) (a) total corpus luteum diameter and (c) progesterone concentration in cows treated with human chorionic gonadotrophin at insemination $(\bigcirc$, day 0$)$, or $7(\boldsymbol{\Delta})$ or 14 $(\triangle)$ days after insemination or untreated control cows $(\square)$. Mean diameter of spontaneous (closed symbols) and induced (open symbols) corpora lutea are shown in (b) for cows treated either on $7(O, \bullet)$ or $14(\square, \boldsymbol{\square})$ days after insemination.

\section{Concentration of progesterone in plasma}

There was a trend for higher progesterone concentrations in plasma of animals treated on day 7 or day 14 than in those treated on day 0 or in controls (Fig. 2c). Concentrations were significantly $(P<0.01)$ influenced by the sampling period. By day 18 after mating, cows treated on day 7 or 14 
had significantly higher progesterone concentrations than cows treated on day 0 or control cows. The respective least-squares means for plasma concentrations were $5 \cdot 3 \pm 1 \cdot 0,7 \cdot 4 \pm 0 \cdot 9,7 \cdot 2 \pm 0 \cdot 8$ and $4.9 \pm 0.8 \mathrm{ng} \mathrm{ml}^{-1}$ for cows treated on day 0,7 or 14 and control cows, respectively. Thereafter, a gradual decline in progesterone was observed in all groups, reaching low concentrations by day 21. At days 35 and 42 , least-squares means for plasma progesterone were higher for cows treated on day 7 .

\section{Pregnancy}

Treatment with hCG was associated with increased pregnancy rates. Three cows in the control group were diagnosed pregnant by ultrasound scanning and rectal palpation. In the hCG-treated group 4, 7 and 4 cows were diagnosed pregnant for cows treated on day 0,7 or 14, respectively. Pregnant cows in day 7 and 14 groups did not correspond to those that developed accessory corpora lutea.

\section{Discussion}

The study showed that seven of nine cows treated with hCG on day 7 after insemination developed accessory corpora lutea. Similar results were reported by Price \& Webb (1989) and Walton et al. (1990) after the use of hCG between days 4 and 7 after oestrus in unmated cows, but without reference to follicular status at the time of administering treatment. The higher incidence of induced ovulations among cows treated on day 7 can be attributed to several factors. Dominant follicles present on day 7 are less likely to be atretic (Rajakoski, 1960; Merz et al., 1981; Bennett et al., 1989; Taylor \& Rajamahendran, 1991b) and have been reported to possess more luteinizing hormone receptors (Bennett et al., 1989). Savio et al. (1990) found that the dominant follicle was ovulatory in about $93 \%$ of heifers after regression of the corpora lutea using a single injection of prostaglandin $\mathrm{F}_{2 \alpha}$ on day 7 after oestrus.

Conversely, a reduction in responsiveness was experienced when hCG was administered on day 14 after insemination. Similar results were reported by Price \& Webb (1989) and by McDermott et al. (1986) in cyclic animals. We (Taylor \& Rajamhendran, 1991b) have previously shown that, in a two-wave pattern of follicular growth, the largest follicle present around day 14 in lactating cows is regressing and therefore atretic. Ireland \& Roche (1982 and 1983) found that such atretic follicles show diminished capability to bind luteinizing hormone during late dioestrus.

The induced ovulations (day 7 and day 14 group) resulted in the development of structures similar in appearance to the spontaneous corpora lutea. Treatment with hCG leads to significant increases in total diameter of corpora lutea. An initial increase in such diameter was evident in all hCG-treated cows and was taken to indicate the response of spontaneous corpora lutea to the luteotrophic effect of hCG. The corpora lutea that were induced by the hCG treatment grew to such an extent that at one point it was difficult to distinguish between spontaneous and induced corpora lutea. Difficulty was also experienced by Price \& Webb (1989) when induced corpora lutea were determined by laparoscopy.

No data are available in the literature on formation and progressional growth of induced corpora lutea in cattle. Results obtained in this study, on a continuous basis using an ultrasonographic technique, provide evidence that the induced corpora lutea: (i) regress with spontaneous corpora lutea, and cows return to oestrus at the normal time (cows treated on day 0 or day 7), although there are indications of slight extension of oestrous cycles among some day 14 cows failing to establish pregnancy; and (ii) are maintained until at least day 80 after fertile inseminations. The extensions in cycle length noted in cows treated on day 14 could have been due to early embryonic mortality, changes in follicular wave pattern and/or disruption of the dominant follicle that is necessary for the initiation of the luteolytic process (Fogwell et al., 1985). 
Treatment of cows with $1000 \mathrm{iu}$ hCG on day 7 or 14 after insemination resulted in increased plasma progesterone. Such increases after hCG treatment at different stages of the oestrous cycle have been reported by others (Mason et al., 1962; Edquin \& Sequin, 1982; Shipley et al., 1988; Breuel et al., 1990). The increased progesterone synthesis could have resulted from hypertrophy of luteal cells in the spontaneous corpora lutea (Veenhuizen et al., 1972; Helmer \& Britt, 1986) and from formation of accessory corpora lutea. The functional aspect of induced corpora lutea was not determined in this study, but the ultrasonographic structure of the induced corpora lutea and the occurrence of the highest progesterone profile in cows treated on day 7 (seven of nine cows formed accessory corpora lutea) indicates that the induced corpora lutea are functional.

Results of experiments on the effect of treatment with hCG on fertility are variable. Brown et al. (1973) and Wagner et al. (1973) found that injection of hCG at mating increased conception rate in beef heifers, but Hansel et al. (1979) and Morris et al. (1976) reported no significant effect of hCG at breeding in lactating cows. Treatment with hCG approximately three days after mating either had no effect or reduced conception rates in beef heifers (Wagner et al., 1973; Morris et al., 1976; Breuel et al., 1990). In this study, seven of nine cows treated with hCG on day 7 were diagnosed pregnant. Little information is available on pregnancy after hCG treatment on day 7 or day 14 after insemination. A large-scale field study carried out by our group (Sianangama et al., 1990) showed a significant increase in pregnancy rates after hCG treatment 7 days after insemination.

This study showed that administration of hCG at different times after mating caused ovulation of large follicles. Ovulatory response was greatest when hCG was given on day 7 after insemination. Induced corpora lutea were not different from spontaneous corpora lutea at the level of ultrasonography and were maintained for the duration of nonfertile oestrous cycles and possibly throughout gestation. Progesterone concentrations after hCG treatment increased in plasma during the experimental period. The incidence of pregnancy was highest when hCG was administered at day 7 after insemination.

The work was supported in part by the Natural Sciences and Engineering Research Council of Canada (Operating Grant) and the Science Council of British Columbia. (STDF 112 SA-2.) We thank D. Bailey for typing the manuscript.

\section{References}

Bennett, W.A., Gonzalez, L.V., Stuart, M.J. \& Fuquay, J.W. (1989) Effects of human chorionic gonadotropin pretreatment on endocrine, cytological and prostaglandin $F_{2} \alpha$ receptor patterns of the bovine corpus luteum. Animal Reproduction Science 19, 179-189.

Breuel, K.F., Spitzer, J.C., Thompson, C.E. \& Breuel, J.F. (1990) First-service pregnancy rate in beef heifers as influenced by human chorionic gonadotropin administration before and/or after breeding. Theriogenology 34, 139-145.

Brown, J., Wagner, J.F., Rathmacher, R.P., McAskill, J.W., Elliston, N.G. \& Bing, R.F. (1973) Effect of human chorionic gonadotropin on pregnancy rate of heifers when used under field conditions. Journal of the American Veterinary Association 163, 456457.

Bulman, D.C. \& Lamming, G.E. (1978) Milk progesterone levels in relation to conception, repeat breeding and influencing acyclicity in dairy cows. Journal of Reproduction and Fertility 54, 447-458.

Edquin, L.O. \& Sequin, B.E. (1982) Corpus luteum function and pregnancy rates in lactating dairy cows given human chorionic gonadotropin at mid-diestrus. Theriogenology 17, 415-422.
Erb, R.E., Garverick, H.A., Randel, R.D., Brown, B.L. \& Callahan, C.J. (1976) Profiles of reproductive hormones associated with fertile and non-fertile inseminations of dairy cows. Theriogenology 5, $227-242$.

Fogwell, R.L., Cowley, J.L., Wortman, J.A., Ames, N.K. \& Ireland, J.J. (1985) Luteal function in cows following destruction of ovarian follicles at midcycle. Theriogenology 23, 389-398.

Hansel, W., Spalding, R.W., Larson, L.L., Laster, D.B., Wagner, J.F. \& Braun, R.K. (1979) Influence of human chorionic gonadotropin on pregnancy rates in lactating dairy and beef cows. Journal of Dairy Science 59, 751-754.

Helmer, S.D. \& Britt, J.H. (1986) Fertility of dairy cattle treated with human chorionic gonadotropin (hCG) to stimulate progesterone secretion. Theriogenology 26, 683-695.

Henricks, D.M., Dickey, J.F. \& Niswender, G.D. (1970) Serum luteinizing hormone and plasma progesterone levels during the estrous cycle and early pregnancy in cows. Biology of Reproduction 2, 346-351.

Holness, D.H., McCabe, C.T. \& Sprowson, G.W. (1982) Observations on the use of human chorionic gonado- 
tropin (hCG) during the post-insemination period on conception rates in synchronized beef cows with suboptimum reproductive performance. Theriogenology 17, 133-140.

Ireland, J.J. (1987) Control of follicular growth and development. Journal of Reproduction and Fertility Supplement 34, 39-54.

Ireland, J.J. \& Roche, J.F. (1982) Development of antral follicles in cattle after prostaglandin-induced luteolysis: changes in serum hormones, steroids in follicular fluid and gonadotropin receptors. Endocrinology 111, 2077-2085.

Ireland, J.J. \& Roche, J.F. (1983) Development of nonovulatory antral follicles in heifers: changes in steroids in follicular fluid and receptors for gonadotropins. Endocrinology 112, 150-156.

Lewis, G.S., Caldwell, D.W., Rexroad, Jr, C.E., Dowlen, H.H. \& Owen, J.R. (1990) Effects of gonadotropinreleasing hormone and human chorionic gonadotropin on pregnancy rate in dairy cattle. Journal of Dairy Science 73, 66-72.

Lukaszewska, J. \& Hansel, W. (1980) Corpus luteum maintenance during early pregnancy in the cow. Journal of Reproduction and Fertility 59, 485-493.

McDermott, J.M., Thatcher, W.W., Drost, M., Martin, J.M. \& Putney, D.J. (1986) Effect of hCG on cycle length, response to $\mathrm{PGF}_{2} \alpha$ and pregnancy rate in dairy cattle. Journal of Animal Science 63 (Supplement 1) (Abstract) 354.

Mason, N.R., Marsh, J.M. \& Savard, K. (1962) An action of gonadotropin in vitro. Journal of Biological Chemistry 237, 1801-1806.

Merz, E.A., Hausser, E.R. \& England, B.G. (1981) Ovarian function in the cycling cow: Relationship between gonadotropin binding to theca and granulosa and steroidogenesis in individual follicles. Journal of Animal Science 52, 1457-1468.

Morris, L.M., Gonzalez-Padilla, E., Niswender, G.D. \& Wiltbank, J.N. (1976) Peripheral progesterone levels in pregnant and non-pregnant heifers following use of hCG. Theriogenology 6, 367-378.

Nakao, T., Narita, S., Tanaka, K., Horn, H., Shirakawa, J., Noshire, H., Saga, N., Tsunoda, H. \& Kawata, K. (1983) Improvement of first-service pregnancy rate in cows with gonadotropin-releasing hormone analogue. Theriogenology 20, 111-119.

Northey, D.L., Barnes, F.L., Eyestone, W.H. \& First, N.L. (1985) Relationship of serum progesterone, luteinizing hormone and the incidence of pregnancy in bovine embryo transfer recipients. Theriogenology 23 (Abstract) 214.

Pierson, R.A. \& Ginther, O.J. (1987) Follicular populations during the estrous cycle in heifers, I: the influence of day. Animal Reproduction Science 14, $165-176$.

Pierson, R.A. \& Ginther, O.J. (1988) Ultrasonic imaging of the ovaries and uterus in cattle. Theriogenology 29, 21-37.

Price, C.A. \& Webb, R. (1989) Ovarian response to hCG treatment during the oestrous cycle in heifers. Journal of Reproduction and Fertility 86, 303-308.

Rajakoski, E. (1960) The ovarian follicular system in sexually mature heifers with special reference to seasonal, cyclical, and left-right variations. Acta Endocrinologica Supplement 52, 7-68.
Rajamahendran, R. \& Taylor, C. (1990) Characterization of ovarian activity in postpartum dairy cows using ultrasound imaging and progesterone profiles. Animal Reproduction Science 22, 171-180.

Randel, R.D., Garverick, H.A., Surve, A.H., Erb, R.E. \& Callahan, C.J. (1971) Reproductive steroid in the bovine. V. Comparisons of fertile and non-fertile cows 042 days after breeding. Journal of Animal Science 33, 104-114.

Robinson, N.A., Leslie, K.E. \& Walton, J.S. (1989) Effect of treatment with progesterone on pregnancy rate and plasma concentrations of progesterone in Holstein cows. Journal of Dairy Science 72, 202-207.

Savio, J.D., Keenan, L., Boland, M.P. \& Roche, J.F. (1988) Pattern of growth of dominant follicles during the oestrous cycle of heifers. Journal of Reproduction and Fertility 83, 663-671.

Savio, J.D., Boland, M.P., Hynes, N., Mattiacci, M.R. \& Roche, R.F. (1990) Will the first dominant follicle of the oestrous cycle of heifers ovulate following luteolysis on day 7? Theriogenology 33, 677-687.

Shipley, S.K., Faquay, J.W., Smith, A.E. \& Stuart, M.J. (1988) Response of dairy heifers to prostaglandin $\mathrm{F}_{2} \alpha$ after treatment with human chorionic gonadotropin. Theriogenology 29, 743-749.

Sianangama, P.C., Rajamahendran, R. \& Fisher, L.R. (1990). Effects of human chorionic gonadotropin (hCG) administration at various times following breeding on progesterone profiles and pregnancy rates in dairy cattle. Canadian Journal of Animal Science 70 (Abstract) 1171 .

Sirois, J. \& Fortune, J.E. (1988) Ovarian follicular dynamics during the oestrous cycle in heifers monitored by real-time ultrasonography. Biology of Reproduction 39, 308-317.

Taylor, C. \& Rajamahendran, R. (1991a) Follicular dynamics and corpus luteum growth and function in pregnant and non-pregnant dairy cows. Journal of Dairy Science 74, 115-123.

Taylor, C. \& Rajamahendran, R. (199lb) Follicular dynamics, corpus luteum growth and regression in lactating dairy cattle. Canadian Journal of Animal Science 71, 61-68.

Veenhuizen, E.L., Wagner, J.F. \& Tonkinson, L.V. (1972) Corpus luteum response to 6-chloro-17-aceto oxyprogesterone and hCG in the cow. Biology of Reproduction 6, 270-276.

Wagner, J.F., Veenhuizen, E.L., Tonkinson, L.V. \& Rathmacher, R.P. (1973) Effect of placental gonadotropin on pregnancy rate in the bovine. Journal of Animal Science 36, 1129-1136.

Walton, J.S., Holbert, G.W., Robinson, N.A. \& Leslie, K.E. (1990) Effects of progesterone and human chorionic gonadotropin administration five days post insemination on plasma and milk concentrations of progesterone and pregnancy rates of normal and repeat breeder dairy cows. Canadian Journal of Veterinary Research 54, 305-308.

Wilmut, I., Sales, D.E. \& Ashworth, C.J. (1985) The influence of variation in embryo stage and maternal hormone profiles on embryo survival in farm animals. Theriogenology 23, 107-119. 